\title{
ARMED FORCES MANAGEMENT AND EMPLOYMENT - NEW DIRECTION FOR PREPARING FUTURE ARMY COMMANDERS OF THE CZECH REPUBLIC Vitezslav JAROS
}

\author{
University of Defence, Brno, Czech Republic, vitezslav.jaros@unob.cz
}

\begin{abstract}
The author describes the content of the new field study of "Armed forces management and employment" and specifies the reasons for its creation in the article. Next the author clarifies the graduate profile, a field of study and study goals. At the same time the location of the subject "Management of military units" is specified, as well as its content and the role in the shaping of the future of combined arms unit commander.
\end{abstract}

\section{Keywords: armed forces, management, military units, study program}

\section{Introduction}

Changes in the security environment at the beginning of the 21 th century and the introduction of a new technology used in modern military weapons of developed armies require a change in an approach to the preparation of military professionals and commanders of land forces in particular. Young commanders of ground units were prepared in accordance with the previous concept, developed at the beginning of the $21^{\text {st }}$ century, when there was also a bachelor, master and doctoral study in a military education system At this time military study was focused on the teaching of economics and the management of the future officers of the Army of the Czech Republic (next only "the Army") in a command, as well as logistics and services areas in the study program "Economics and Management", and in the field of study "Military Management". The past years have shown that the preparation of future commanders of the ground forces of the Army did not fully meet the requirements of the praxis in the focus and in achieving an ideal graduate profile and that teaching should focus not only on the Military Management, but also more on Military Leadership.

On this basis, the University Graduate Profile of a future commander of ground forces has been recently reassessed and a new field of study "Armed Forces management and employment" was created.

\section{Field of study "Armed forces} management and employment"

The new field of study is designed for a university preparation of future commanders of ground forces of the Army, focusing on mechanized, tank, motorized, infantry, artillery, engineer and chemical specializations at our University of Defense. The field of study is focused on theoretical subjects, especially in the field of economics, management and leadership and their application into specific conditions of ensuring national security and defense, including specificities resulting from the activities of military units. Students learn management and leadership skills necessary for the performance of command and other management functions at the Army troops. 
The study program "Economics and Management" with the new field of study "Armed Forces management and employment" are designed so as to implement descriptors for master's degree in the education of the Economics and the Economy of the National Qualifications Framework. This extension continues on the general concept of the theoretical part of the study program that carries on general knowledge and skills into the application level corresponding to the specific conditions of ensuring national defense and security, respectively the conditions of operations of the armed forces. The study program also satisfies the descriptors of master's level of education of Security fields of studies, the subarea Army and Defense of the National Qualifications Framework. The structure and content of the application part of the study program reflects the learning outcomes required by the Ministry of Defense.

\subsection{Structure of the new field of study}

The new field of study is structured into four blocks (see Figure 1). The first one is called General theoretical curriculum including academic subjects focused on the development of general knowledge and skills necessary for managing organizations and their economies. Parts of the theoretical basis are also subjects that are considered prerequisites of a successful leader in the area of security and defense and, in a broader context, they enable to independently interpret and to assess current issues of a dynamically evolving security environment. The subjects of a theoretical basis create prerequisites for the following application blocks of the study program.

The second block is created by academic subjects of the applied curriculum. These subjects transfer the general theoretical knowledge and skills into circumstances of the management of a military organization from elementary to middle management levels. An emphasis is placed on the management of operations of a military unit in normal peace time conditions, including resource management, the organization of training activities, as well as the deployment of military forces in crisis situations, having both military and nonmilitary character. Particular attention is devoted to the preparation and leadership of personnel. The subjects of applied curriculum are compulsory for all students in the field of study.

The third block is a set of compulsory elective subjects, so-called study modules. These study modules correspond to the focus existing in the profession requirements on personnel in various command and economic specializations (professions) in the Army. By selecting one of the nine modules of compulsory elective subjects, students receive specialized professional knowledge and skills appropriate to the specific requirements of the Ministry of Defense related to work on command or economic positions in the structures of specific kinds of forces and other components of the Department of Defense.

The fourth block of study includes the subjects of the new field of study for all students of all years of study and other blocks of study involve the development of language skills and physical fitness of students.

\subsection{University Graduate Profile}

The graduates of the Master's study program of "Economics and Management" of the field of study "Armed Forces management and employment" receive a broad theoretical foundation focused on the application of management and economic tools and techniques in the military and government administration areas. At the same time, the graduates acquire professionally-oriented competencies needed for effective actions during the management of processes such as training and deployment of military troops on command and staff positions at the elementary and middle management levels of the armed forces. In the wider context of 
the security environment, the graduates have the capability to propose and apply the methods, procedures and means to control military units, both under normal conditions and in crisis situations, having both a military and non-military character. They are physically fit, able to communicate in English at a professional level and ready to be deployed in a culturally different or diverse environment. The graduates of master degree of the study program of "Economics and Management" and of the field of study "Armed forces management and employment" acquire the expertise, skills and general competences that will be presented below.

\section{Professional knowledge}

The graduates will acquire broad theoretical knowledge which will allow them to understand the theories, concepts and methods of modern economics and management. They able to apply the acquired knowledge in the management of security processes in the armed forces conditions.

\section{Professional skills}

By the theoretical and professionally oriented knowledge gained during the years of study, the graduates are able to exercise the managerial roles of an Army officer - as commanders or as specialists responsible for managing the organizational parts of the Ministry of Defence. At the same time, they know how to use and evaluate managerial decision support tools and practically apply innovative methods and approaches to solve complex and difficult predictable situations.

\section{General competences}

The graduates are generally capable to apply a wide range of critical knowledge and skills necessary for the successful management of the role of Army officer, acting as managers or economists in the area of management and ensuring national security and defense.

They are able to analyze problems, to identify the available alternatives of solution associated with the emergence of contingency situations and to propose appropriate precautions in order to reduce the impact of problems. They are capable to formulate and implement the plans for fulfilling the selected variants, and to meet the economic, legal and ethical standards of conduct.

\section{The subject "Management of military units"}

The subject "Management of military units" is included only in the module "Combined arms unit commander", which due to its content is not fully understandable (see Figure 1). The content of the subject "Management of military units" is focused on an introduction of students to the issue of peace time life in the units and formations of the Army and on the place and role of a unit commander in its implementation. At the same time the subject deals in detail with the preparation of the Army personnel at the unit level.

The first part of the subject's content is aimed at an introduction of students to the basic regulations and documents necessary for the performance of functions of unit commanders and their practical application in acting as unit commanders, including the processing and exploitation of unit commander's documentation.

The second part of the subject focuses on clarifying the system with regard to the preparation (the methods and techniques) of the Army as future subordinates.

The subject "Training Methods" follows up the subject "Management of military units". Students practically apply the forms and methods of the preparation of subordinates in the conditions of the University of Defense. Students process documentation for the management of training of future subordinates, using appropriate methods of preparation, such as the explanation, exercise, Command Post Exercise and Field Exercise.

The module and subject sponsor clearly declared the necessity to introduce students of all modules with an issue that creates content of the subject when sponsor created the structure of the study. Not all sponsors 
of the modules agreed, they preferred the professional aspect of the content of module subjects against of gaining command ability of future graduates.

\section{Conclusion}

The structure and contents of the field of study "Armed Forces management and employment" reflect the new conditions in which the Army is currently involved. The future employer of the graduates of this study program - the Ministry of Defense transformed these changed conditions into demands for professional knowledge, skills and general competences that the graduates should possess since they are assigned to work as officers in the structures of the
Armed Forces of the Czech Republic, mainly as commanders or in other managerial positions. The requirements of the Ministry of Defense have led to a closer connection between the general and the applied part of the study program and to a linking of the theoretical subjects with the subjects focusing on the development of practical skills. In accordance with the requirements of the founder, an increased emphasis was also put on the graduates' practical knowledge and skills necessary for a successful profession and well performed functions after they have completed their studies.

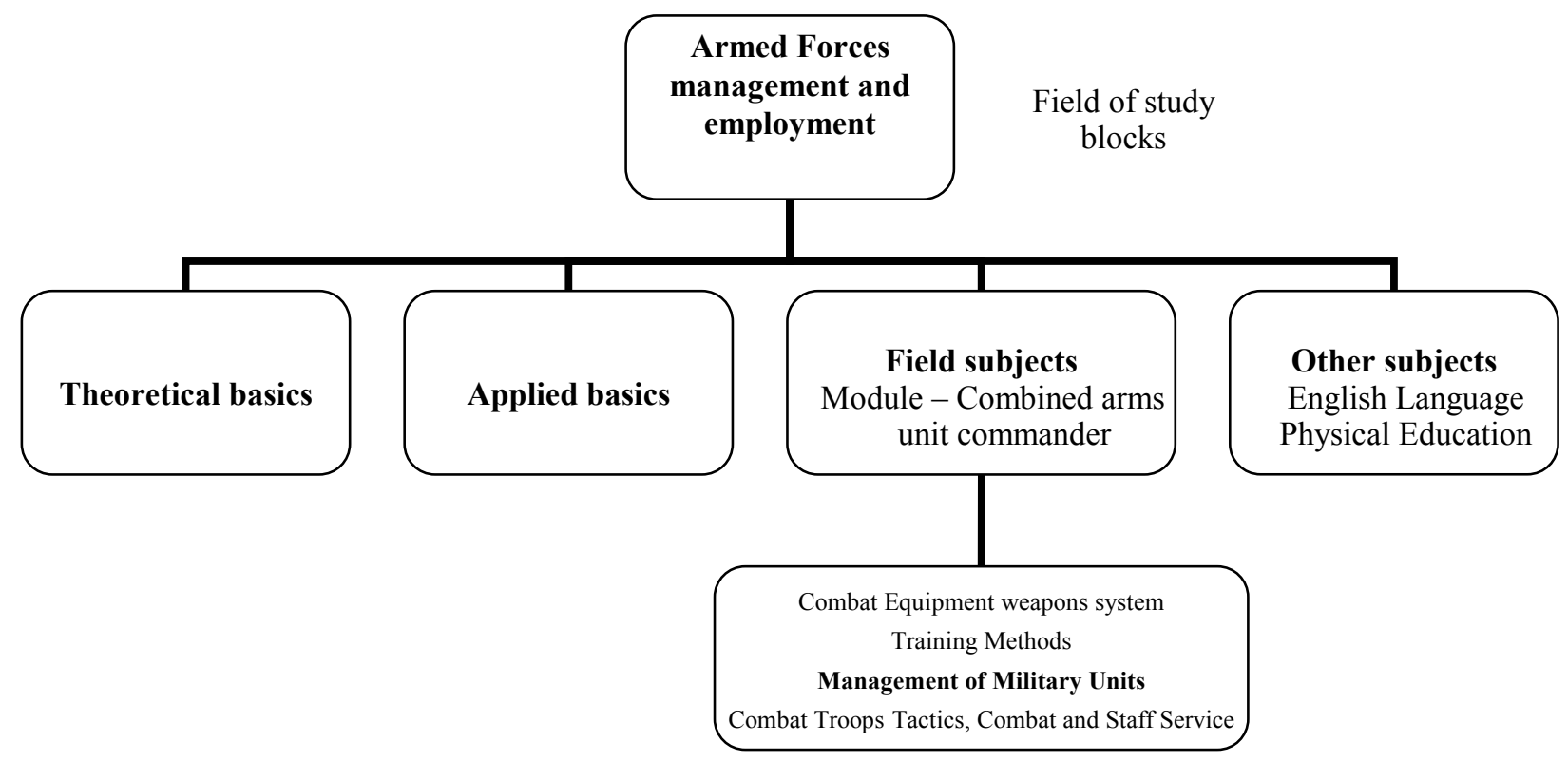

Figure 1: Blocks of the new field of study "Armed forces management and employment" described on the Module - Combined arms unit commander

\section{References}

[1] Application for Accreditation of Master's degree in study field Armed Forces management and employment in the study program "Economics and Management", FVL, Brno, 2013, p. 206

[2] Jaros, V., Management of military units, Application for Accreditation of Master's degree in study field Armed Forces management and employment in the study program "Economics and Management", FVL, Brno, 2013, p. 92

[3] Pub-70-01-01, Příprava př́slušníků AČR, MoD, Vyškov, DD, 2007, p. 264 